\title{
DISTANCE AND FACE-TO-FACE STUDENTS' PERCEPTIONS TOWARDS DISTANCE EDUCATION: A COMPARATIVE METAPHORICAL STUDY
}

\author{
Ayse BAGRIACIK YILMAZ \\ ORCID: https://orcid.org/0000-0002-9971-2440 \\ Faculty of Education, Aydin Adnan Menderes University \\ Aydin, Turkey
}

Received Date: 07/02/2018 Accepted Date: 16/10/2018

\begin{abstract}
The aim of this study is to determine and compare the metaphorical perceptions of face-to-face and distance education students towards distance education. The research was conducted using phenomenology pattern. Research data were obtained from 80 distance education students and 56 face-to-face education students using metaphorical perception form for distance education. Data were analyzed with the content analysis technique. Analysis of the data showed that distance education students produced 66 metaphors while faceto-face students produced 55 metaphors. In both groups, metaphors were grouped under three categories. Considering the categories, it was seen that "provided opportunities" and "limitations" categories emerged in both groups. Distance education is not indispensable for face-to-face students. Some of the distance education students prefer distance education because of desperation. As for sub-categories, it was seen that unlike face-to-face students, distance education students -perceived distance education as a road to dreams and they thought that distance education provided them to study while working in a job. While the most repeated metaphors in distance education students were "a golden blessing, a great opportunity, and indispensable", face-to-face students repeated the "essential" metaphor the most.
\end{abstract}

Keywords: Distance education, student perceptions, metaphorical perception, qualitative research.

\section{INTRODUCTION}

Distance education is a form of education in which students are often or always physically separated from the instructor and the educational institution. Learning can take place in groups or individually or even without the instructor. This form of learning can be used blending with face-to-face learning. Students have to use some communication technologies in order to communicate with other students and the instructor in this form of education (Moore \& Kearsley, 2012; Simonson, Smaldino \& Zvacek, 2015). In distance education, students take their own responsibility for learning. Students should define their own goals, determine how they will reach these goals and how much they need to learn, create a learning plan, and evaluate their own learning (Zhao, Chen, \& Panda, 2014).

Online learning is one of the most popular forms of distance education. It is a learning experiment which the learning content was delivered to students through technology, online course materials, and online interactions. Online learning allows education to reach a wide variety of student groups (Al-Ashmoery, 2015; Andrade, 2015; Fedyinch, Bradley \& Bradley, 2015). 
In recent years, a variety of studies were carried out to determine the students' perceptions of online learning quality (Jung, 2012). Bhagat, Wu, and Chang (2016) discussed the perceptions of students about online learning in four dimensions: instructor characteristics, social presence, instructional design, and reliability. According to Jung's (2011) study, the factors effecting the quality of e-learning are interaction, staff support, institutional quality assurance mechanisms, institutional trust, student support, information and publicity, and learning tasks. Similarly, a year later, Jung (2012) has tested the quality of distance education with a conceptual model consisting of ten dimensions: school's support of faculty, student support, information and publicity, course development, teaching and learning, interactive tasks, measurement and evaluation, infrastructure, internal quality assurance mechanisms and institutional reliability. As a result, it was determined that all these dimensions are important for evaluating the quality of distance learning.

Ward, Peters and, Shelley (2010) have found out that both instructors and students had a positive perception towards online learning. Based on the findings of their study, they have stated that the effectiveness of faceto-face learning could be provided in online learning, too. Furthermore, Lenka and Kant (2012) correlated the perception of online learning with biological variables. Oteng-Ababio (2011) determined that students had positive opinions in terms of providing satisfaction, the usefulness, and flexibility of distance education but negative perceptions about the exams. Especially, it was found that the untimely delivery of modules, poorly regulated modules, and exam programs were disturbing for students. According to Chen and Chen (2006), students have positive perceptions about the effectiveness of e-learning. Cigdem and Topcu (2013) also determined that the most important factor effecting students' satisfaction of e-learning is perceived usefulness. Perceived usefulness and perceived satisfaction varied according to the program in which students enrolled.

Perception is the process of gaining awareness, and understanding the environment by editing and interpreting information (Lenka \& Kant, 2012). It is obvious that many studies were conducted to determine the perception of students about distance learning/online learning/e-learning. One of the methods used to identify the perception towards a subject is to determine the metaphors, which individuals have about the subject.

Metaphor and its usage in the description is one of the issues currently attracting the researchers' attention. It is indicated that there are numerous studies focusing on metaphorical perception in both national and international research area (McHaffie, 2000; Saban, 2009). A metaphor is a powerful mental tool that can be used to identify an abstract, complex and theoretical phenomenon with another phenomenon (Saban, Kocbeker \& Saban, 2006). Kemp (1999) defined the metaphor as a shape of conversation in which something is described by likening it to another thing. Lakoff and Johnsen (2003) emphasized that metaphor is not only something about poetic imagination and words but also a concept related to thoughts and actions which are widely used in daily life. Additionally, they stated that actually, individuals' ordinary conceptual system is inherently metaphorical in terms of thinking and acting. Metaphors which have been known since classical times and have seen as valuable, and which is a natural part of a human communication through language (Falconer, 2008) help people to explain something by associating it with another thing (Saban, Kocbeker, \& Saban, 2006). Furthermore, metaphors may provide a new insight for the history and everyday experience. Metaphors produced by students can help to understand the dominant experiences in the program (Kemp, 1999; Lakoff \& Johnson, 1980).

Meyer (2005) stated that metaphors could have advice about what distance education is and how students learn in distance education. It is important to determine how metaphors affect the understandings of individuals about the potential of distance education or how they are blocking the emergence of alternative ideas. Students can have various perceptions about online learning, and this leads students to produce various 
different metaphors. Metaphors used in distance education may contain clues about the views of the present and future role of distance education (Meyer, 2005; Tuncay \& Ozcinar, 2009).

There is a limited number of studies in the literature conducted in order to determine the metaphorical perceptions of students about distance education, and types of distance education. One of the most comprehensive studies was carried out by Tuncay and Ozcinar (2009). The researchers conducted the study to determine the face-to-face students' metaphorical perceptions about distance education and discovered that students produced quite different metaphors such as "ocean". Besides they have recommended that the metaphors about distance education should be investigated in a comprehensive manner. Falconer (2008) has carried out a study to examine the use of a metaphor for the purposes of teaching in online learning environments. However, this study was related to the only use of the metaphors not to the metaphorical perception. Senyuva and Kaya (2013) have conducted a study to determine the metaphorical perceptions of nursing students about the internet. The researchers have ascertained that students perceived the internet as an information source and they thought that it should be used consciously. In light of all these information, this study is considered to be significant in terms of determining students' perceptions of distance education and their opinions about the positive and negative aspects of distance education. Furthermore, this study is expected to provide valuable information to the literature because it compares the metaphorical perceptions of face-to-face and distance education students.

In this study, it is aimed to determine and compare the distance education and face-to-face education students' metaphorical perceptions of distance education. In this context, the research questions are as follows:

Which metaphors do face-to-face education students have about the concept of distance education?

$>$ Through which metaphors do the distance education students explain the perception they have about the concept of distance education?

$>$ How do metaphorical perceptions of distance education differ between face-to-face students and distance education students?

\section{METHOD}

\section{Research Model}

This study was based on the qualitative research model. Qualitative studies aim to reveal the events and perceptions in a realistic and holistic manner, and in a natural setting by using qualitative data collection tools (Yildirim \& Simsek, 2013). Miles and Huberman (1994) have stated that qualitative studies provide rich and integrated content and they have great potential to reveal complex cases. In this study, students' perceptions of distance education were examined in detail without any intervention.

\section{Research Design}

In this study, phenomenology, one of the qualitative study patterns was used. Studies based on facts that we have no in-depth and detailed understanding are called phenomenological research (Yildirim \& Simsek, 2013). Phenomenological research defines the common meaning of individuals' experiences about a phenomenon or a concept (Creswell, 2013).

\section{Study Group}

The study group was determined by using the criterion sampling method which is one of the purposive sampling methods. The logic of criterion sampling is to select all cases providing certain criteria (Patton, 2014). In accordance with the features of criterion sampling, individuals from whom the data will be 
collected should be experiencing the specified case and be capable of reflecting this case (Yildirim \& Simsek, 2013).

In this context, there are two criteria in the study. The first criterion is that all students who are in distance education group have to be receiving courses at distance (through video conference and supported by a learning management system) and the second is that the face-to-face students should at least have some information about distance education. Computer and Instructional Technology Education (CEIT) Department students have courses about distance education, therefore, they have knowledge about it. In this context, data was collected during the 2015-2016 academic year from 115 distance education students who are studying in Computer Engineering, Industrial Engineering, Management Information Systems and CEIT departments of Ahmet Yesevi University and 59 face-to-face students in CEIT Department of Gazi University. However, only 80 metaphors from distance education students and 56 metaphors from face-toface students could be used for some reasons such as inconsistency between descriptions and metaphors, repeated data and irrelevant metaphors.

\section{Data Collection}

"...... is like ......; because......." sentence pattern is commonly used in metaphorical perception studies (Saban, 2009). Accordingly, in this study data were collected using the "Metaphorical Perception Form for Distance Education" form, which was developed by the researcher considering the subject area expert opinions and common usage in the literature. In this form, students were asked to fill in two gaps: "Distance education is like ...... because ...........". The aim of the data collection tool is not only to obtain metaphors, but also to learn why students indicate the metaphors. For this reason, in order to gain deeper knowledge, to understand the student's perception more reliably (Ekici, 2016), the question of "because........" is added. Data collection tool was implemented by the researcher to the face-to-face education students, and the electronic version of the form was delivered to distance education students via e-mail by the information technologies department of the university.

\section{Data Analysis}

Data were analyzed using the content analysis method. This method consists of coding, identifying themes, and organizing the data according to codes and themes (Miles \& Huberman, 1994). Because this study is a metaphorical study, codes were obtained from the metaphors stated by students. In order to ensure the reliability of the study, "compliance percentage" proposed by Miles and Huberman (1994) was calculated. Compliance percentage formula is as follows: Reliability $=($ Consensus $) /[($ Consensus $)+($ Dissensus $)] \times 100$. Because the categorization process was made separately for face-to-face students and distance education students, the compliance percentage was calculated separately for each categorization process. In order to calculate the percentage of compliance, metaphors are firstly divided into categories and subcategories by a researcher. The convenience of the categories was discussed with another researcher, and then the researcher put the metaphors under the identified categories. After this process, the compliance percentage between the two encoders was found to be $68 \%$ for the face-to-face group and the $49 \%$ for the distance education group. Thereupon, the researchers performed the categorization process over again discussing incompatible categories. Later on, the compliance percentage was calculated as $\% 89$ for both face-to-face and distance education groups. According to Miles and Huberman, at least $70 \%$ compliance for reliability between coders is required. Thus $89 \%$ indicates that the desired confidence level is reached.

\section{FINDINGS}

\section{Determining Face-to-face Education Students' Metaphorical Perceptions of Distance Education}

Under this heading, metaphors stated by face-to-face students about distance education, categories under which these metaphors were grouped and examples of metaphors for each category are given. 
When Table 1 is examined, it is seen that students use all the metaphors only once, except "essential" $(\gamma=2)$. Indeed, when looking at the descriptions of metaphors, it is seen that many metaphors in the table indicate very similar things. For instance, 23 of the metaphors emphasize that "distance education is independent of time and place" (see Table 2). Sample descriptions for the metaphors are given in Table 3.

Table 1. Metaphors stated by face to face students about distance education

\begin{tabular}{|c|c|c|c|c|c|}
\hline $\begin{array}{l}\text { Metaphor } \\
\text { sequence }\end{array}$ & Metaphor name & $f$ & $\begin{array}{l}\text { Metaphor } \\
\text { sequence }\end{array}$ & Metaphor name & $f$ \\
\hline 1 & Essential & 2 & 29 & $\begin{array}{l}\text { The system I dislike when I } \\
\text { need }\end{array}$ & 1 \\
\hline 2 & Chili pepper & 1 & 30 & Ladle & 1 \\
\hline 3 & Encyclopedia & 1 & 31 & Dictionary in my library & 1 \\
\hline 4 & Stay in purgatory & 1 & 32 & Library & 1 \\
\hline 5 & Elevator & 1 & 33 & Make-up & 1 \\
\hline 6 & $\begin{array}{l}\text { Do more work with less } \\
\text { energy }\end{array}$ & 1 & 34 & Spaceless school & 1 \\
\hline 7 & Freedom & 1 & 35 & Music & 1 \\
\hline 8 & $\begin{array}{l}\text { Feast relatives came only } \\
\text { to feast }\end{array}$ & 1 & 36 & Breath & 1 \\
\hline 9 & Breast milk for babies & 1 & 37 & Virtual world & \\
\hline 10 & Free home & 1 & 38 & Virtual classroom & 1 \\
\hline 11 & Knowledge competition & 1 & 39 & Magic wand & 1 \\
\hline 12 & Vessels in a body & 1 & 40 & Political programs & 1 \\
\hline 13 & $\begin{array}{l}\text { Learn many things from } \\
\text { my location }\end{array}$ & 1 & 41 & cold sandwiches & 1 \\
\hline 14 & Safety pin & 1 & 42 & Social network & 1 \\
\hline 15 & Chocolate & 1 & 43 & Social networking site & 1 \\
\hline 16 & $\begin{array}{l}\text { The place where I earn my } \\
\text { livelihood }\end{array}$ & 1 & 44 & Continuous innovation & 1 \\
\hline 17 & Orders from home & 1 & 45 & My phone & 1 \\
\hline 18 & My home school & 1 & 46 & To add salt to salty food & 1 \\
\hline 19 & $\begin{array}{l}\text { Elementary school, high } \\
\text { school, college of future }\end{array}$ & 1 & 47 & Airplane & 1 \\
\hline 20 & $\begin{array}{l}\text { Higher education of } \\
\text { future }\end{array}$ & 1 & 48 & Kite & 1 \\
\hline 21 & $\begin{array}{l}\text { Imagination remaining } \\
\text { training }\end{array}$ & 1 & 49 & Something very easy to reach & 1 \\
\hline 22 & Life & 1 & 50 & $\begin{array}{l}\text { Paid internships and an area } \\
\text { that I developed myself }\end{array}$ & 1 \\
\hline 23 & $\begin{array}{l}\text { Breakfast I made every } \\
\text { morning }\end{array}$ & 1 & 51 & Bed & 1 \\
\hline 24 & Fast train & 1 & 52 & $\begin{array}{l}\text { A watch without the hour and } \\
\text { minute hand }\end{array}$ & 1 \\
\hline 25 & Hobbies implemented & 1 & 53 & Food & 1 \\
\hline 26 & $\begin{array}{l}\text { The person comes to my } \\
\text { rescue when I need }\end{array}$ & 1 & 54 & Non-compulsory course & 1 \\
\hline 27 & Medicine & 1 & 55 & $4,5 \mathrm{G}$ & 1 \\
\hline \multirow[t]{2}{*}{28} & To reach the desired thing & 1 & & & \\
\hline & & & & TOTAL VIEW & 56 \\
\hline
\end{tabular}


Table 2. Distribution of metaphors in categories (stated by face-to-face students)

\begin{tabular}{llll}
\hline Categories & & $\begin{array}{l}\text { The number of } \\
\text { metaphors }(\mathrm{f})\end{array}$ & $\%$ \\
\hline \multirow{2}{*}{\begin{tabular}{l} 
1.1. Structural opportunities \\
\cline { 2 - 4 }
\end{tabular}} & $\begin{array}{l}\text { Time and place } \\
\text { independence }\end{array}$ & 23 & 32,86 \\
\cline { 2 - 4 } $\begin{array}{l}\text { Others } \\
\text { Instructional } \\
\text { opportunities }\end{array}$ & 13 & 18,57 \\
\hline $\begin{array}{llll}\text { 1.3. } \quad \text { Financial opportunities } \\
\text { 2. Limitations }\end{array}$ & 14 & 20 \\
\hline 3. Not to be indispensable & & 4 & 5,71 \\
\hline & Total & 10 & 8,57 \\
\hline
\end{tabular}

According to Table 2, an important part of the metaphors $(\mathrm{n}=56)$ are related to the opportunities provided by distance education. While ten metaphors emphasize that distance education is not indispensable, four metaphors mention the limitations of distance education. Totally, students stated 55 metaphors but because some metaphors are related to more than one category, the total number of metaphors under categories is seen as 70. Metaphors for each category/subcategory, and the sample explanations for the categories/subcategories were given in Table 3, Table 4 and Table 5.

Table 3. Metaphors located under the "opportunities provided" theme and sample explanations

\begin{tabular}{|c|c|c|c|}
\hline Theme & Category & Subcategory & The number of metaphors $(\mathrm{f}=54)$ \\
\hline \multirow{4}{*}{$\begin{array}{l}\text { Opportun } \\
\text { ities } \\
\text { Provided }\end{array}$} & 1.1. Structural & $\begin{array}{l}\text { Time and place } \\
\text { independence }\end{array}$ & $\begin{array}{l}\text { Essential (1), Do more work with less energy (6), Freedom } \\
\text { (7), Free home (10), Learn many things from any place } \\
\text { (13), Orders from home (17), My home school (18), } \\
\text { Elementary school, high school, college of future (19), Life } \\
\text { (22), To reach the desired thing (28), Library (33), } \\
\text { Spaceless school (34), Virtual classroom (38), Magic wand } \\
\text { (39), Social networking site (43), My phone (45), Plane } \\
\text { (47), Kite (48), Something very easy to reach (49), Bed } \\
\text { (51), A watch without hour and minute hand (52), Non- } \\
\text { compulsory course (54) }\end{array}$ \\
\hline & & Others & $\begin{array}{l}\text { Chili pepper (2), Elevator (6), Do more work with less } \\
\text { energy (6), Vessels in a body (12), Safety pin (14), Fast } \\
\text { train (24), Dictionary in my library (31), Breath (36), } \\
\text { Cold sandwich (41), Social network (42), Paid internships } \\
\text { and an area that I developed myself (50), Bed (51) }\end{array}$ \\
\hline & $\begin{array}{l}1.2 . \\
\text { Instructional }\end{array}$ & & $\begin{array}{l}\text { Essential (1), Breast milk for babies (9), Knowledge } \\
\text { competition (11), Vessels in a body (12), Safety pin (14), } \\
\text { Elementary school, high school, college of future (19), } \\
\text { Higher education of future (20), Breakfast I made every } \\
\text { morning (23), Hobbies implemented (25), Ladle (30), } \\
\text { Library (32), Virtual world (37), Virtual classroom (38), } \\
\text { Continuous innovation (44) }\end{array}$ \\
\hline & 1.3. Financial & & $\begin{array}{l}\text { Free home (10), The place where I earn my livelihood } \\
\text { (16), Hobbies implemented (25), Paid internships and an } \\
\text { area that I developed myself (50) }\end{array}$ \\
\hline
\end{tabular}


Sample explanations for "Time and place independence" sub category:

PF: (Person-Face to Face) shows quotations from the face to face education students.

My phone; I can get what I want and when I want without losing time (PF16)

Magic wand; Spaceless and timeless, accessible anywhere, anytime (PF27)

Bed; It is a system that you can access easily when you want (PF36)

Sample explanations for "Other opportunities" sub category:

Fast Train; You can go away immediately (PF28).

Elevator; It creates a new way to the people even inhibits the sports provided by stairs (PF48).

Dictionary in my library; I can search anything that prepossess me when I need. (PF53).

Sample explanations for "Instructional opportunities" sub category:

Library; I get the information I need when I want (PF1).

Higher education of future; People can meet their training needs, professional development and personal development needs by getting a profession at an early age through distance education. Distance education is the most efficient way for these (PF11).

Vessels in a body; Vessels distribute the heart pumped blood throughout the body. Distance education is like this. What a teacher tells reaches thousands of students (PF33).

Sample explanations for "Financial opportunities" sub category:

Hobbies implemented; I can get training all areas I wish. I can overcome the moral and material problems (PF7).

The place where I earn my livelihood; I work part-time at distance education centre of the university. I earn a little money there and it makes me feel better. I also learn many things there (PF8).

Paid internships and an area that I developed myself; A good experience for me in my student life (PF17).

When Table 3 is examined, it is seen that there were 54 metaphors $(77.14 \%)$ under the "opportunities provided by distance education" theme. Metaphors are grouped under the structural opportunities, instructional opportunities and financial opportunities categories. Additionally, structural opportunities category is divided into 2 sub categories of "independence of time and space" and "other". Students mostly emphasized time and space independence of distance education (32.86\%). Distance education is considered as a system which is capable of delivering the desired information easily at any place or time without the obligation to go to the school. In the "others" category, structural opportunities stated by the students except time and place independence are located. In this category, some features of distance education were settled such as being fast, funny, flexible, practical etc.

The instructional opportunities of distance education (20\%) is another feature stated by the students. According to the students, distance education provides lifelong learning. Besides, distance education is massive, in another words distance education can reach very large audiences of different ages and abilities, and it has the potential to take the place of face-to-face education in the future. Distance education has very wide and rich sources of information and everyone can benefit from these resources as they wish.

There are financial opportunities provided by distance education $(5.71 \%)$, too. In this category, most of the statements about working in a distance education centre are located because face-to-face students haven't benefited sufficiently from distance education. One student noted that distance education was economic and financial difficulties can be overcome with distance education. 
Table 4. Metaphors located in the "limitations" category and sample explanations

\begin{tabular}{ll}
\hline Category & Number of the metaphors ( $\mathrm{f}=6)$ \\
\hline \multirow{3}{*}{ 2. Limitations } & $\begin{array}{l}\text { Stay in purgatory (4), Imagination remaining training (21), The system I } \\
\text { dislike when I need (29), Political programs (40), To add salt to salty } \\
\text { food (46), 4,5 G (55) }\end{array}$ \\
\hline
\end{tabular}

Sample explanations for "Limitations" category ;

4,5 G;You have many expectations but you get nothing (PF3).

Imagination remaining training; There is no teacher and classroom neither (PF52)

To add salt to the salty food; I think distance education is unnecessary and certainly should not be in this way. Students usually don't care about these courses (PF56).

When the metaphors stated under the "limitations" category are examined, it is seen that students mentioned some limitations of distance learning such as not meeting expectations, being bored or not having a classroom environment. In addition, one of the students indicated that she could not feel herself as a student. Another student stated that distance education was student-centred and she did not like the student-centred education. Besides, some of students stated that they use distance education only for their needs or because they have no other choice.

Table 5. Metaphors located in the "not to be indispensable" category and sample explanations

\begin{tabular}{ll}
\hline Category & Number of Metaphors $(\gamma=10)$ \\
\hline & $\begin{array}{l}\text { Encyclopaedia (3), Feast relatives came only to feast (8), Knowledge } \\
\text { 3. Not to be indispensable }\end{array}$ \\
& $\begin{array}{l}\text { (26), Medicine (27), Make-up (33), Music (35), Cold sandwich (41), Food } \\
\text { (53) }\end{array}$
\end{tabular}

Examples of explanation for "Not to be indispensable" category;

Music, it is in every aspect of our lives but if not we don't feel a lack (PF30).

Make up, it is in my life when necessary, but it is not indispensable if I don't need it (PF39).

Feast relatives came only to feast, I don't visit him as long as I do not have to see him (PF51).

Examining table 5, it is seen that some of the students stated that they would use distance education only when they need it, and when they were done with distance education they would remove it from their life. However, some of them stated that the value of distance education could change from person to person. They also stated that distance education meant a lot for the people who want to get something from it while it would not mean anything for others.

\section{Determining Distance Education Students' Metaphorical Perceptions of Distance Education}

Under this heading, metaphors stated by distance education students, categories under which these metaphors were grouped, and examples of metaphors for each category are given in tables.

Table 6. Metaphors stated by distance education students about distance education

\begin{tabular}{llllll}
\hline $\begin{array}{l}\text { Metaphor } \\
\text { Sequence }\end{array}$ & Metaphor Name & $f$ & $\begin{array}{l}\text { Metaphor } \\
\text { Sequence }\end{array}$ & Metaphor Name & $f$ \\
\hline 1 & A golden blessing & 7 & 34 & Fast food & 1 \\
\hline 2 & A great opportunity & 3 & 35 & Bus, arriving late & 1 \\
\hline
\end{tabular}




\begin{tabular}{|c|c|c|c|c|}
\hline 3 & Indispensable & 36 & $\begin{array}{l}\text { The opportunity I found on } \\
\text { the ground while searching } \\
\text { in the sky }\end{array}$ & 1 \\
\hline 4 & Flotation ring & 37 & $\begin{array}{l}\text { The opportunity to make my } \\
\text { dreams real }\end{array}$ & 1 \\
\hline 5 & Gift & 38 & A new gateway to life & 1 \\
\hline 6 & Medicine & 39 & The opportunity of my life & 1 \\
\hline 7 & Essential & 40 & $\begin{array}{l}\text { Peacefully played violin, } \\
\text { piano, guitar }\end{array}$ & 1 \\
\hline 8 & 3-wheel bike & 41 & A second chance & 1 \\
\hline 9 & 5-stars formal education & 42 & Take medicine & 1 \\
\hline 10 & A formidable mountain & 43 & Internet & 1 \\
\hline 11 & Honey & 44 & Online shopping & 1 \\
\hline 12 & Compensation of some regret & 45 & $\begin{array}{l}\text { To find money in the pocket } \\
\text { of winter coat. }\end{array}$ & 1 \\
\hline 13 & Using computer & 46 & Penny bank & 1 \\
\hline 14 & A step & 47 & Nuts & \\
\hline 15 & hit two birds with one stone & 48 & Tea with lemon & 1 \\
\hline 16 & Our village & 49 & $\begin{array}{l}\text { The way that makes easy to } \\
\text { get education. }\end{array}$ & 1 \\
\hline 17 & Bridges on the Bosphorus & 50 & $\begin{array}{l}\begin{array}{l}\text { Alternative to formal } \\
\text { education }\end{array} \\
\end{array}$ & 1 \\
\hline 18 & Mobile phone & 51 & Freedom & 1 \\
\hline 19 & Tea & 52 & An expensive gift & 1 \\
\hline 20 & $\begin{array}{l}\text { To eat the stale chickpeas in } \\
\text { the cookie plate }\end{array}$ & 53 & To play street ball & 1 \\
\hline 21 & Crumpets in thick syrup & 54 & My last remedy & 1 \\
\hline 22 & Dual nationality & 55 & The newest system machine & 1 \\
\hline 23 & Democracy & 56 & Dessert & 1 \\
\hline 24 & $\begin{array}{l}\text { An integral part of educational } \\
\text { life }\end{array}$ & 57 & $\begin{array}{l}\text { The voice on the end of the } \\
\text { line }\end{array}$ & 1 \\
\hline 25 & Revolution in education & 58 & $\begin{array}{l}\text { To see the train on the } \\
\text { railway platform while } \\
\text { thinking missed it }\end{array}$ & 1 \\
\hline 26 & To live freedom in education & 59 & Remote control & 1 \\
\hline 27 & The free face of education & 60 & Writhe in a long well & 1 \\
\hline 28 & $\begin{array}{l}\text { The most practical educational } \\
\text { tool }\end{array}$ & 61 & Pangs of conscience & 1 \\
\hline 29 & My favourite thing & 62 & $\begin{array}{l}\text { Earn money from where you } \\
\text { lie. }\end{array}$ & 1 \\
\hline 30 & $\begin{array}{l}\text { To watch my favourite film at } \\
\text { home without going to the } \\
\text { cinema }\end{array}$ & 63 & A new opportunity & 1 \\
\hline 31 & The school at home and in bus & 64 & $\begin{array}{l}\text { The car picks you up while } \\
\text { you hitchhiking. }\end{array}$ & 1 \\
\hline 32 & The classroom in our house & 65 & YouTube & 1 \\
\hline \multirow[t]{2}{*}{33} & Services from our house & 66 & Saving of time & 1 \\
\hline & & & TOTAL VIEW & 80 \\
\hline
\end{tabular}


When Table 6 is examined it is seen that students mostly stated the metaphor "golden blessing" ( $\mathrm{f}=7$ ). Besides, while "a great opportunity" and "indispensable" were repeated three times and "Flotation ring, Gift, Medicine, and Essential" were repeated twice, remaining metaphors were stated only once. These statements indicate that distance education students have a quite positive perception of distance education. Themes, categories and subcategories created considering the metaphors stated by the distance education students are given in Table 7.

Table 7. Distribution of the metaphors in categories (stated by distance education students)

\begin{tabular}{llll}
\hline Categories & \multicolumn{1}{l}{ Subcategories } & Number of Metaphors $(f)$ & $\%$ \\
\hline & $\begin{array}{l}\text { Time and place } \\
\text { independence }\end{array}$ & 27 \\
\cline { 2 - 4 } $\begin{array}{l}\text { 1.1.Structural opportunities } \\
\text { Being able to } \\
\text { continue education } \\
\text { while working in a job }\end{array}$ & 24 & 21.82 \\
\cline { 2 - 4 } & Others & 16 & 14.54 \\
\hline $\begin{array}{l}\text { 1.2. Instructional } \\
\text { opportunities }\end{array}$ & 16 & 14.54 \\
\hline $\begin{array}{l}\text { 1.3. The way to dreams } \\
\text { 1.4. Financial } \\
\text { opportunities }\end{array}$ & 8 & 7.27 \\
\hline 2. Limitations & 7 & 6.36 \\
\hline 3. Desperation & 7 & 6.36 \\
\hline
\end{tabular}

When Table 7 is examined it is seen that a very large part of the metaphors (90.07\%) stated by distance education students as well as the face-to-face students (77.14\%) are about the opportunities provided by distance education. The most important point to be considered in this table is that "being able to continue education while working in a job" $(21.82 \%)$ and "a road to dreams" (7.27\%) categories were added to opportunities provided by distance education which is different from the categories of the face-to-face students. Probably, face-to-face students ignored the "being able to continue education while working in a job" aspect of distance education because they have not got any job yet. Besides, in addition to the categories of face-to-face students, "desperation" (4.54\%) category is included. What students mean with "desperation" and "a road to dreams" is discussed in detail in the following tables. Metaphors for each category/subcategory and the sample explanations for the categories/subcategories were given in Table 8, Table 9, and Table 10.

Table 8. Metaphors located under the "opportunities provided" theme and sample explanations

\begin{tabular}{|c|c|c|c|}
\hline Theme & Category & Sub Category & Number of Metaphors $(j=99)$ \\
\hline $\begin{array}{l}\text { Opportuni } \\
\text { ties } \\
\text { Provided }\end{array}$ & $\begin{array}{l}\text { 1.1. Structural } \\
\text { opportunities }\end{array}$ & $\begin{array}{l}\text { Time and place } \\
\text { independence }\end{array}$ & $\begin{array}{l}\text { A great opportunity (2), Medicine (6), 5-stars formal } \\
\text { education (9), Crumpets in thick syrup (21), } \\
\text { Democracy (23), An integral part of educational life } \\
\text { (24), Revolution in education (25), To live freedom } \\
\text { in education (26), The most practical educational } \\
\text { tool (28), My favourite thing (29), To watch my } \\
\text { favourite film at home without going to the cinema } \\
\text { (30), The school at home and in bus (31), The } \\
\text { classroom in our house (32), Services from our house } \\
\text { (33), Fast food (34), The opportunity I found on the }\end{array}$ \\
\hline
\end{tabular}


ground while searching in the sky (36), Peacefully played violin, piano, guitar (40), Online shopping (44), Alternative to formal education (50), Freedom (51), To play street ball (53), Dessert (56), The voice on the end of the line (57), Remote control (59), Youtube (65), Saving of time (66)

\begin{tabular}{|c|c|c|}
\hline & $\begin{array}{l}\text { Being able to } \\
\text { continue } \\
\text { education while } \\
\text { working in a job }\end{array}$ & $\begin{array}{l}\text { Golden blessing (1), A great opportunity (2), } \\
\text { Indispensable (3), Flotation ring (4), Gift ( } 5 \text { ), } \\
\text { Essential (7), Honey (11), A step (14), Hit two birds } \\
\text { with one stone (15), Bridges on the Bosporus (17), } \\
\text { Dual nationality (22), A second chance (41), Tea with } \\
\text { lemon (48), The way that makes easy to get education } \\
\text { (49), Alternative to formal education (50), My last } \\
\text { remedy (54) }\end{array}$ \\
\hline & Others & $\begin{array}{l}\text { A golden blessing (1), Indispensable (3), 3-wheel bike } \\
\text { (8), Using computer (13), Our village (16), Mobile } \\
\text { phone (18), Tea (19), The free face of education (27), } \\
\text { The opportunity I found on the ground while } \\
\text { searching in the sky (43), To find money in the } \\
\text { pocket of winter coat (45), Nuts (47), Freedom (51), } \\
\text { Earn money from where you lie (62) }\end{array}$ \\
\hline $\begin{array}{l}1.2 . \\
\text { Instructional } \\
\text { Opportunities }\end{array}$ & & $\begin{array}{l}\text { A golden blessing (1), Indispensable (3), Gift (5), } \\
\text { Compensation of some regret (12), Crumpets in thick } \\
\text { syrup (21), An integral part of educational life (24), } \\
\text { The classroom in our house (32), Fast food (34), } \\
\text { Peacefully played violin, piano, guitar (40), To find } \\
\text { money in the pocket of winter coat (45), Nuts (47), } \\
\text { Freedom (51), The newest system machine (55), A } \\
\text { new opportunity (63), The car picks you up while } \\
\text { you hitchhiking (64) }\end{array}$ \\
\hline $\begin{array}{l}\text { 1.3. The way to } \\
\text { dreams }\end{array}$ & & $\begin{array}{l}\text { Flotation ring (4), A step (14), The opportunity to } \\
\text { make my dreams real (37), The opportunity of my } \\
\text { life (39), A second chance (41), To find money in the } \\
\text { pocket of winter coat (45), An expensive gift (52), To } \\
\text { see the train on the railway platform while thinking } \\
\text { missed it (58) }\end{array}$ \\
\hline $\begin{array}{l}\text { 1.4. Financial } \\
\text { opportunities }\end{array}$ & & $\begin{array}{l}\text { Indispensable (3) Flotation ring (4), A step (14), } \\
\text { Crumpets in thick syrup (21), An integral part of } \\
\text { educational life (24), A new gateway to life (38), } \\
\text { Penny bank (46) }\end{array}$ \\
\hline \multicolumn{3}{|c|}{$\begin{array}{l}\text { lanations for "Time and place independence" sub category: PD: Person-Distance shows } \\
\text { of distance education students. } \\
\text { dom in education; It does not require the time and space to learn (PD4) } \\
\text { tunity I found on the ground while searching in the sky; As one of the person who is exposed } \\
\text { s of formal training for years in three different university, I think be able to study engineering } \\
\text { hile drinking my tea is incredibly pleasant and comfortable (PD31). } \\
\text { ntrol; It bring the same opportunity to you, without having to go to school (PD12). }\end{array}$} \\
\hline
\end{tabular}


Sample explanations for "Being able to continue education while working in a job" sub category: A step; I think studying while working in a job would move me to a top spot in the industry (PD64). Golden blessing; I am married and I have three children, besides I can't get off work. But, through distance education I raise my education level (PD75).

A gift; Because it is a great opportunity to complete their education for employees, those who have to work and people with disabilities (PD14).

Sample explanations for "Others" sub category:

A golden blessing; there is no compulsory attendance (PD77)

Using computer; Everything can be solved with a click (PD60)

Internet; I can get instant access to my courses and notes (PD22)

Sample explanations for "Instructional Opportunities" sub category:

The newest system machine; it provides opportunity to students to convert theoretical knowledge to practice (PD23).

Fast Food; If you don't have enough time, then you apply to distance education to improve your education level (PD72).

Crumpets in thick syrup; Depending on the instructor distance education can be much more quality and understandable from face to face education. Beside this, distance education prevents inconveniences while going to school and meanwhile it avoids unnecessary hours spent. People can get quality education from where they sit and the can listen courses again and again whenever they want. If the instructor is dedicated she answers all the questions instantly and she can serve additional materials so can doubles the understandability of the course by face to face education.

Sample explanations for "The way to dream" sub category:

The opportunity to make my dreams real; I always want to study on computers and electronics (PD74).

The opportunity of my life; My greatest dream is to become an engineer (PD42).

To see the train on the railway platform while thinking missed it; To learn that I could reach my dream while I was thinking that I am late for my dream of becoming an engineer (PD38).

Sample explanations for "Financial opportunities" sub category:

Penny bank; It helps to increase our savings (PD21).

A step; I think studying while working in a job would move me to a top spot in the industry (PD64). Indispensable; Thanks to emerging communication systems (personal computer, smartphones, iPad, internet networks, etc.) it is extremely easy access to information (PD50).

When Table 8 is examined, it is seen that students stated 99 metaphors (97.07\%) about the opportunities provided by distance education. Distance education students stated that distance education is a road to dreams $(7.27 \%$ ), and they mentioned the same categories (structural opportunities, instructional opportunities, and financial opportunities) with face-to-face students. Distance education students mostly emphasized the feature of being independent of time and place $(25.54 \%)$ as face-to-face students did. One of the most important findings of the research is that category named "being able to continue education while working in a job" $(21.82 \%)$ is very important for distance education students but not for the face-toface students. Face-to-face students did not even mention it. Besides, under the "others" category, metaphors which belong to the features of being fast, flexible, funny etc. are gathered. 
Students emphasized the instructional opportunities of distance education (14.54\%) such as the wealth of the course contents, availability of the teaching staff, and providing learning opportunity based on interest etc. Some students mentioned educational opportunities provided by distance learning by comparing the distance education to face-to-face education. Distance education is seen as "the way to dreams" $(7.27 \%)$ by distance education students. Because a large part of these students are working in a job, they are only able to continue their education through distance education. Some students are also able to resume the education which they left in the past for some reasons. It is thought that "the way to dreams" category was not stated by the face-to-face students because their age and experiences are different from the distance education students.

Distance education students, like face-to-face students, also mentioned the financial opportunities of distance education. However, a different point stands out here. As the face-to-face education students emphasized much more about the aspect of making money by working in distance education centers, distance education students mentioned that distance education was economic in terms of time and money, and it allows for earning money through providing the opportunity for both working and learning. It can be said that the determinations of individuals who experienced the distance education personally are more realistic.

Table 9. Metaphors located under the "limitations" category and sample explanations

\begin{tabular}{ll}
\hline Category & Number of metaphors $(t=7)$ \\
\hline \multirow{3}{*}{ 2. Limitations } & Medicine (6), A formidable mountain (10), Our village (16), Bus, arriving \\
& late (35), The voice on the end of the line (57), Writhe in a long well (60), \\
& Pangs of conscience (61)
\end{tabular}

Sample explanations for "Limitations" category:

Bus, arriving late, Although not timely, delivers you to your destination (PD52)

Writhe in a long well, You need to do research on your own to get to the source of knowledge (PD9).

Pangs of conscience, I think I would be an engineer without learning enough (PD55).

When Table 9 is examined, it is seen that distance education students stated the limitations of distance education $(6.36 \%)$ as the face-to-face students did. Some of the students complained about the lack of dedicated instructors and some of them stated that distance learning provided the easy way to get a certificate/diploma.

Table 10. Metaphors located under the "desperation" category and sample explanations

\begin{tabular}{|c|c|}
\hline ry & \\
\hline Desperation & $\begin{array}{l}\text { 17), To } \\
\text { Tea wi }\end{array}$ \\
\hline \multirow{2}{*}{\multicolumn{2}{|c|}{$\begin{array}{l}\text { Sample explanations for "Desperation" category: } \\
\text { 3ridges on the Bosporus; We have no alternative way to become an engineer while we are working in a } \\
\text { ob (PD20). }\end{array}$}} \\
\hline & \\
\hline \multicolumn{2}{|c|}{$\begin{array}{l}\text { To eat the stale chickpeas in the cookie plate; The most fresh and delicious parts of the cookies are eaten } \\
\text { and so we can only eat the remaining rotten cookies (PD40). }\end{array}$} \\
\hline & \\
\hline
\end{tabular}

Metaphors stated by students who preferred distance education because of desperation and some examples of explanations about those metaphors are located in Table 10. According to this, these students preferred distance education not very willingly, they preferred it because they had no other choice. However, when 
compared with the opportunities provided by distance education $(90.07 \%)$, it is seen that the rate of the "desperation" category (4.54\%) is lower than opportunities.

\section{DISCUSSIONS AND CONCLUSION}

In this study, metaphorical perceptions of face-to-face students and distance education students about distance education were determined, and then categories and sub-categories under which these metaphors were gathered were compared between two groups. Both of the two groups stated that distance education provided structural, instructional and financial opportunities, but besides these opportunities, it has some limitations. The structure is related to what extent the curriculum can adapt or respond to students' individual needs (Moore, 1993). Distance education provides students a lot of structural flexibility. In distance education, individuals can study in their own time and from their own place as Naidu (2014) has stated. Additionally, students mentioned that distance education has many instructional opportunities such as studying the learning material again and again and accessing the latest materials about the subject. Similar results have been reached in the literature (Allen, Bourhis, Burrell, \& Marby, 2002; Ally, 2008; Boling, Hough, Krinsky, Saleem, \& Stevens, 2012).

Ally (2008) has stated that students are able to continue their education even in the workplace thanks to the flexibility of distance education, in other words, they have the opportunity to study while working in a job. While structural opportunities were divided into "time and place independence" and "others" sub-categories in the face-to-face students, "being able to study while working in a job" was added as a sub-category along with these categories by the distance education students. This difference between the groups may because of the fact that one of the groups have no distance learning experience. As it has been stated by Shen, Co, Tsai, and Marra (2013) previous distance learning experience effects students' perceptions.

The physical separation of students and instructor in terms of time and place is the keystone of the distance education (Moore, 1996). When this separation is psychological and communicational, the transactional distance which occurred between students and the instructor can be an obstacle to efficient learnings (Moore, 1993). Indeed, some of the distance education students emphasized that sometimes they need more communication with the instructor. This result Paechter, Marier and Macher (2010) have stated that the best predictors for learning achievement and course satisfaction are students' perceptions of the instructor's expertise in e-learning, and her/his counseling and support.

Distance education offers opportunities that could make conditions more equitable for disadvantageous groups to continue their education or to improve themselves (Robinson, 2008). In this study, some students stated that they resumed their education thanks to the distance education and some stated they study in a department which they cannot even imagine. Distance education helps the students to continue their education by overcoming many obstacles. However, some distance education students stated that they prefer distance education because of desperation. Many of the students are working in a job, thus they have no other alternative to receive an undergraduate education. Similarly, face-to-face students stated that distance education was not indispensable. Many studies (Allen et al., 2002; Powell, 2007) indicated that satisfaction levels of distance education students are as high as face-to-face students. However, as noted by Simonson (1997) some students prefer distance education because it is convenient for them, despite the fact that they do not want to receive distance education. To overcome this situation, it may be useful to make arrangements to engage students in the learning process more.

Finally, it can be said that distance education has both opportunities and limitations. Face-to-face students and distance education students have common and different perceptions of distance education. However, the perception of distance education students is more positive because they experience it personally and it 
provides many opportunities to them such as studying while working and studying in the department that they always dreamed about.

\section{LIMITATIONS AND FUTURE RESEARCH}

Distance education students participated in this study were studying at a private university. Therefore, different results can be obtained from the students who are studying at a public university. It is suggested to include a public university's students to the study group for future researches. Besides, face-to-face students participated in this research were studying in a department related to computer science. More comprehensive information about the technical problems experienced in distance education can be obtained from the students of the departments which are not related to computer science.

\section{BIODATA and CONTACT ADDRESSES of AUTHOR}

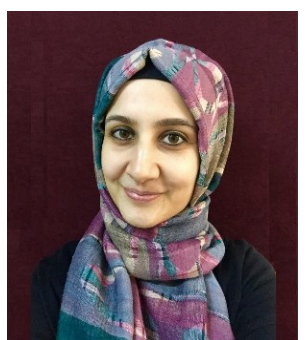

Ayse BAGRIACIK YILMAZ is a research assistant in Department of Computer Education and Instructional Technologies Education at Aydın Adnan Menderes University. She has gained her M.A. degree from Gazi University. She has been doing her Ph.D. on distance education since 2015. Her studies focus on distance education, online learning, interactive learning environments, instructional technologies and educational technologies. She has 2 journal articles published in international indexes, 1 international book chapter, and 8 national and international articles, papers presented at international conferences.

\section{Ayse BAGRIACIK YILMAZ}

Department of Computer Education and Instructional Technologies Education, Faculty of Education Address: Aydın Adnan Menderes University, 09000, Aydın, Turkey

Phone: +90 2562142023,

E-mail: ayse.yilmaz@adu.edu.tr

\section{REFERENCES}

Allen, M., Bourhis, J., Burrell, N., \& Mabry, E. (2002). Comparing student satisfaction with distance education to traditional classrooms in higher education: A meta-analysis. The American Journal of Distance Education, 16(2), 83-97.

Ally, M. (2008). Foundations of educational theory for online learning. In Terry Anderson (Ed.), The theory and practice of online learning (pp. 15-45). Canada: Athabasca University Press.

Al-Ashmoery, Y., Messoussi, R., \& Touahni, R. (2015). Analytical tools for visualisation of interactions in online e-learning activities on LMS and semantic similarity measures on text. Journal of Theoretical and Applied Information Technology, 73(1).

Andrade, M. S. (2015). Teaching Online: A Theory-based Approach to Student Success. Journal of Education and Training Studies, 3(5), 1-9.

Bhagat, K. K., Wu, L. Y., \& Chang, C. Y. (2016). Development and validation of the perception of students towards online learning (POSTOL). Journal of Educational Technology \& Society, 19(1), 350-359.

Boling, E. C., Hough, M., Krinsky, H., Saleem, H., \& Stevens, M. (2012). Cutting the distance in distance education: Perspectives on what promotes positive, online learning experiences. The Internet and Higher Education, 15(2), 118-126. 
Chen, T. L., \& Chen, T. J. (2006). Exploring learner perception of e-learning effectiveness in the workplace learning context based on diffusion of innovations (DOI) model. Online Submission. Retrieved from http://files.eric.ed.gov/fulltext/ED518676.pdf.

Creswell, J. W. (2013). Nitel arastırma yontemleri: Bes yaklasıma gore nitel arastırma ve arastırma deseni. (Mesut Butun \& Selcuk Besir Demir, Trans. Eds.). Ankara: Siyasal.

Cigdem, H., \& Topcu, A. (2013). Students' perception of e-learning in the technical vocational school. Science Journal of Turkish Military Academy, 23(2), 1-19.

Ekici, G. (2016). Ogretmen Adaylarının "Bilgisayar" Kavramına İliskin Metaforik Algıları. Gaziantep University Journal of Social Sciences, 15(3).

Falconer, L. (2008). Evaluating the use of metaphor in online learning environments. Interactive Learning Environments, 16(2), 117-129.

Fedynich, L., Bradley, K. S., \& Bradley, J. (2015). Graduate students' perceptions of online learning. Research in Higher Education Journal, 27, 1.

Jung, I. (2011). The dimensions of e-learning quality: from the learner's perspective. Educational Technology Research and Development, 55(4), 445-464.

Jung, I. (2012). Asian learners' perception of quality in distance education and gender differences. The International Review of Research in Open and Distributed Learning, 13(2), 1-25.

Kemp, E. (1999). Metaphor as a tool for evaluation. Assessment \& Evaluation in Higher Education, 24(1), 81-89.

Lakoff, G., \& Johnson, M. (1980). Metaphors we live by. Chicago: The University of Chicago.

Lenka, S. K., \& Kant, R. (2012). A Study of Attitude and Perception of the Learners towards Distance Education in Relation to Their Biographical Factors. Turkish Online Journal of Distance Education, 13(4), 236-244.

Meyer, K. (2005). Common metaphors and their impact on distance education: What they tell us and what they hide. The Teachers College Record, 107(8), 1601-1625.

McHaffie, P. (2000). Surfaces: tacit knowledge, formal language, and metaphor at the Harvard Lab for Computer Graphics and Spatial Analysis. International journal of geographical information science, 14(8), 755-773.

Miles, M. B., \& Huberman, M. (1994). Qualitative data analysis. An expanded sourcebook (2nd ed.). New Delhi: Sage.

Moore, M. G., \& Kearsley, G. (2005). Distance education: A systems vieu. USA: Thomson Learning.

Naidu, S. (2014). Enabling time, pace and place independence. In J. Michael Spector, M. David Merrill, Jan Elen, M. J. Bishop (Eds.), Handbook of research on educational communications and technology (pp.259-268).NewYork:Springer.Retrieved from https://books.google.com.tr/books?id=oVlHAAAAQBAJ\&dq=time+and+place+independence $\&$ $\mathrm{hl}=\operatorname{tr} \& \mathrm{lr}=$

Oteng-Ababio, M. (2011). Door of hope or despair: Students' perception of distance education at University of Ghana. Turkish Online Journal of Distance Education, 12(3).

Paechter, M., Maier, B., \& Macher, D. (2010). Students' expectations of, and experiences in e-learning: Their relation to learning achievements and course satisfaction. Computers \& education, 54(1), 222-229. 
Patton, M. K. (2014). Nitel arastrrma ve degerlendirme yontemleri Qualitative research and Evoluation Methods]. (M. Butun-S. B. Demir, Trans. Eds.). Ankara: Pegem.

Powell, D. C. (2007). Student satisfaction with a distance learning MPA program; A preliminary comparison of on-campus and distance learning students' satisfaction with MPA courses. MERLOT Journal of Online Learning and Teaching, 3(1).

Robinson, B. (2008). Using Distance Education and ICT to Improve Access, Equity and the Quality in Rural Teachers' Professional Development in Western China. International Review of Research in Open and Distance Learning, S(1), 1-17.

Saban, A. (2009). Ogretmen adaylarının ogrenci kavramına iliskin sahip oldukları zihinsel imgeler. Turk Egitim Bilimleri Dergisi, $7(2)$.

Saban A. Kocbeker B. N. Saban A.(2006) Ogretmen adaylarının ogretmen kavramına iliskin algılarının metafor analizi yoluyla incelenmesi. Kuram ve Uygulamada Egitim Bilimleri 6(2).

Shen, D., Cho, M. H., Tsai, C. L., \& Marra, R. (2013). Unpacking online learning experiences: Online learning self-efficacy and learning satisfaction. The Internet and Higher Education, 19, 10-17.

Simonson, M. 1997. Does anyone really want to learn at a distance? Contemporary Education 68(2), 1047.

Simonson, M., Smaldino, S., \& Zvacek, S. (2015). Teaching and learning at a distance. Foundations of distance education. North Carolina: Information Age.

Senyuva, E., \& Kaya, H. (2013). Metaphors for the internet used by nursing students in Turkey: A qualitative research. Eurasian Journal of Educational Research, 50, 87-106.

Tuncay, N., \& Ozcinar, Z. (2009). Distance sducation students' “metaphors”. Procedia-Social and Behavioral Sciences, 1(1), 2883-2888.

Ward, M. E., Peters, G., \& Shelley, K. (2010). Student and faculty perceptions of the quality of online learning experiences. The International Review of Research in Open and Distributed Learning, 11(3), 57-77.

Yildirim, A., \& Simsek, H. (2013). Sosyal bilimlerde nitel arastırma yontemleri[Qualitative Research in Social Sciences]. Ankara: Seckin.

Zhao, H., Chen, L., \& Panda, S. (2014). Self-regulated learning ability of Chinese distance learners. British Journal of Educational Technology, 45(5), 941-958. 